\title{
FACTORS EFFECTING THE COST MANAGEMENT IN CONSTRUCTION PROJECTS
}

\author{
A M Faten Albtoush, S I Doh, Abdul Rahimi Bin Abdul Rahman \\ Faculty of Civil Engineering \& Earth Resources, Universiti Malaysia Pahang, \\ 26300 Gambang, Pahang, Malaysia \\ Ja'far A.Aldiabat Albtoush \\ Jerash Uneversity, Jerash, Jordan, Irbid International Street \\ Jerash, 26150, Jordan
}

\begin{abstract}
Cost management is an important stage in construction project life cycle, construction projects need cost management in the first stage to finish the project within required cost, time and quality, it's considered as the most factors affecting in the success of construction projects in all developing and developed countries. Many researchers focused to studying the factors affected in cost performance in construction projects in different countries, because cost is an important attribute in construction projects. The project considered as success project when it finished within limited cost and time with required quality, the three items (cost, time and quality) depend on each other, any change in one of them affects the other, whether the effect was positive or negative, the main item of them is cost, so this encourage many researchers to study the factors affected in cost management. This research is carried out to highlight the information on the factors that affected in cost management during the life cycle on construction project, the data collected through 41 reviews focused in studying factors affected in cost performance of construction project. In this research it is to be found different factors in different countries and different projects, the most important factors found through literature review are: design changes, poor management in the site, delay in progress payment by owner, fluctuation in material price.
\end{abstract}

Keywords: cost management, construction project, success project.

Cite this Article: A M Faten Albtoush, S I Doh, Abdul Rahimi Bin Abdul Rahman and Ja'far A.Aldiabat Albtoush, Factors Effecting the Cost Management in Construction Projects. International Journal of Civil Engineering and Technology 11(1), 2020, 105-111.

http://iaeme.com/Home/issue/IJCIET?Volume $=11 \&$ Issue $=1$ 


\section{INTRODUCTION}

Construction sector is an important sector in developed and developing countries and affects other sectors in direct and indirect ways. Therefore, special attention should be given to control and manage it wisely particularly in the aspect of cost management. Cost management is one of the important factors determining project complete successfully within limited time with reasonable profit. Cost management can be defined as a strategic process that stresses the optimization of efficiency and focuses on the customer and on profitability, it is "a philosophy", "an attitude" and "a set of techniques" to create more value at lower cost, that consisting of six steps including: Understanding of what causes the cost and revenue structure of the business, Understand and reduce inter-functional complexity, Provide the tools to manage costs, Involve employees in decisions, Increase effectiveness and continuously improve costs, Measure decisions against the strategic business plan $[1,2]$.

Burke et al [3] suggested that there are two types of construction cost: Direct cost as material, labour and equipment, Indirect cost as general overhead and job overhead, these costs need to be controlled and managed. Halepota [4] recommended eight techniques in construction projects, namely: budget planning and control, estimating, budgeting, cash flow forecasting, financial reporting and cost reporting, cost code systems, value management and judgement.

Cost planning should be applied in order to reduce problems through the life cycle of construction projects, the six overall cost planning advantages proposed by Ashworth \& Perera [5] are as the follows: 1) the tender amount is more likely to match the approved budget estimate, 2) there is less possibility of addendum in bills of quantities or re-costing being required, 3) it is more likely to achieve cost-effectiveness and value for money design, 4) a more rational design is likely to result in a balanced distribution of expenditure, 5) the amount of pre-tender analysis by the architect and quantity surveyor should make it possible to take more decisions earlier, resulting in a smoother running of the project on site, 6) a sound basis for comparing different projects is cost planning.

The aim of this research is to review the past literatures that studied factors influencing the cost performance in construction projects, to highlight the information on the factors that affected in cost management during the life cycle on construction project, in order to encourage other researchers to study these factors in other way to reduce its problems in the future

\section{PROBLEMS OF COST MANAGEMENT}

Construction projects are a huge sector in all countries, because it involved different types of works which need various materials, experiences, equipment, techniques and specializations. These need to be managed and plane, so cost management is important in the construction projects. Many researchers study the cost performance in different stages through the life cycle of construction projects, Life cycle costing as an important contribution to feasibility study in construction projects [6], a decision-making scheme for the investors, allowing evaluation of not only investment costs, but also of life cycle savings and benefits is crucial, thus shifting the objective from decision-making based only on the construction costs towards life cycle costs [7]. Cost overrun is a major problem in project development and is a regular feature in construction industry [8], one of the reasons of cost overruns in construction projects is rework. The cost impact value represents the cost effect of rework, if it happens, and consists of two parts. The first part is the total daily rate of successor activity, which includes daily salaries and daily overheads. The second part is related to any other costs (other than the daily rate of successor activity) [9]. There are many problems impact in cost overrun as determined by various studies, for example Ahmed et al [10] stated that minor delays are 
often neglected because they develop slowly during the construction process, but their cumulative effect impacts the project financially. Another studies concluded that insufficient basic project data and a delay in the process of preparing, submitting and approving shop drawings could adversely affect the schedule and cost performance of project $[11,12$, 13].According to Sriprasert [14] inefficient construction management and poorly established cost control systems cause cost overruns. Koushki et al [15] revealed that material-related issues contribute to cost overrun. In addition to that, a project might be face different problems because of inaccurate, incomplete or untimely information [16].

\section{FACTORS AFFECTING IN COST MANAGEMENT}

Cost management is one of the fundamental criteria of success in construction projects, thus it should be managed and control along the lifecycle of the project, the study focused on evaluation of cost management practices in large construction project in south Malaysia, the results indicated the most effective cost management techniques were: Cash Flow Forecasting, Tender Budgeting/Estimating and Elemental Cost Plan [17]. The most important factors that affected in cost management of construction projects in South-western Nigeria were: poor leadership and inappropriate management, inefficient deployment of resources, excessive wastage of materials on sites, complex payment mechanisms, theft of materials on sites and variation during construction works [18].

Iyer \& Jha [19] indicated the success and failure factors from literature review to found the factors affecting cost performance of Indian construction projects, the results of questionnaire survey concluded that the Critical success factors obtained by the analyses were: project managers competence; top management support; project managers coordinating and leadership skill; monitoring and feedback by the participants; coordination among project participants; and owners' competence and favourable climatic condition, on the hand, the factors affecting the cost performances of projects, were: conflict among project participants; ignorance and lack of knowledge; presence of poor project specific attributes and nonexistence of cooperation; hostile socio economic and climatic condition; reluctance in timely decision; aggressive competition at tender stage; and short bid preparation time.

Cost estimation is an important stage in the cost management of construction projects as mentioned by Hatamleh et al [20], to estimate the cost of construction project there is an important element should be considered as: Comprehensive information, expanded knowledge, considerable expertise, and continuous improvement to have accurate estimation, this study identified the factors that affected in cost estimation to increase accuracy in cost estimation of projects, the most important factors that affecting the accuracy in cost estimation were: clear and detail drawings and specification, pricing experience of construction projects, perception of estimation importance, equipment (cost/availability/ performance), project complexity, clear scope definition, accuracy and reliability of cost information, site constraints (access, storage, services), material availability, financial capabilities of the client, and availability of database of bids on similar project (historical data).

The study of Sinesilassie et al [21] aimed to indicate and evaluate the factors affected in success of cost performance in Ethiopian public construction projects, the research method followed the steps below: Identification of attributes affecting project, Performance, Development of questionnaire, Selection of respondents, Data analysis method, the results emerged seven success and six failure factors which affected in cost performance of Ethiopian public construction projects. 


\section{These factors were:}

Success factors: Project manager's competence, Scope clarity, Owner's competency, Monitoring and feedback, Coordination and communication among project Participants, Top management support, Quality control and assurance.

Failure factors: Conflict among project participants, Project specific factor, Indecisiveness of project participant, Project manager's ignorance and lack of knowledge, Socio-economic and climatic condition, Owner's incompetence.

The key factors affecting construction performances are: 1) Time, 2) Cost, 3) Quality, 4) Safety \& Health, 5) Internal Stakeholder, 6) External Stakeholder, 7) Client Satisfaction, 8) Financial Performance, 9) Environment, and 10) Information, Technology \& Innovation. Which indicated through developed a multidimensional performance evaluation framework for a construction company [22].

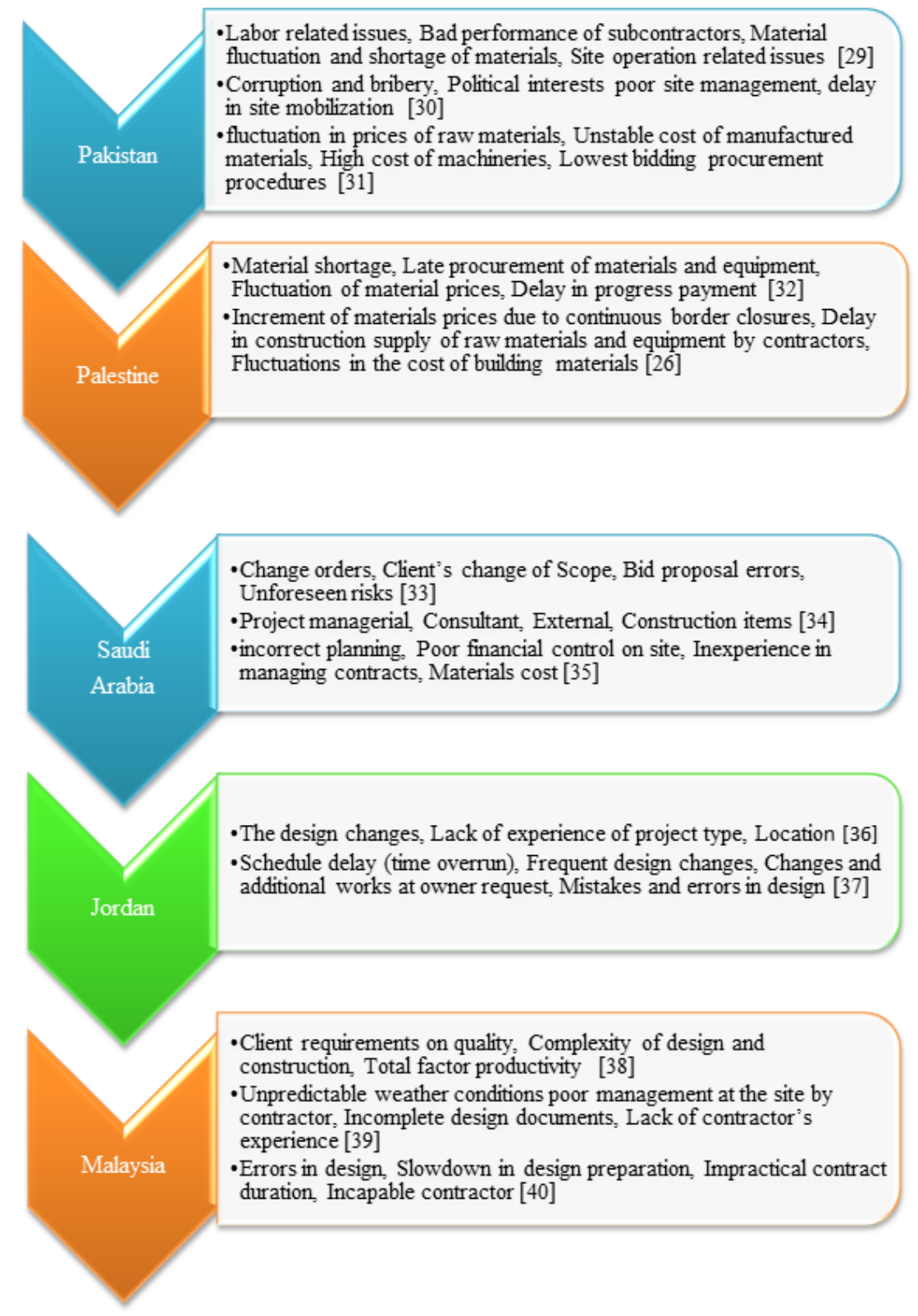

Figure 1 Main Factors of Cost Management in Different Countries 
Cost overrun is observed as the most frequently problem found in construction projects which impact in the cost management of projects in different countries, this agreed with Shehu et al [23] stated that, the majority of construction projects in Malaysia suffering from cost overrun, for example In Afghanistan construction cost overrun, Niazi [24] was reviewed through studying literature review, sixty-nine causes of project cost overruns classified in three Categories, these causes were initiated by: Client, Contractor, Consultant, the most important factors were: corruption, delay in progress payments by clients, difficulties in financing project by contractors, security, and change order by clients during construction phase. India have little studies in cost overrun of construction projects according to Wanjari \& Dobariya [25], revealed in its study that cost overrun in India have little studies, the researcher indicated 15 factors to be ranked through a questionnaire survey distributed to construction professionals across India (northern region, southern region, western region, eastern region and central regions) and only three factors indicated as a most important in causing cost overrun of the construction projects in India, which are: price escalation of raw material, delay in planned activity and lack of co-ordination between construction parties. In order to reduce the impact of these factors on cost overruns, the framework of each factor is suggested.

The main factors of cost overrun in construction projects in the Gaza Strip are: price fluctuations of construction materials, contractor delays in material and equipment delivery, and inflation, while the importance factors of delay were as follow: strikes and border closures, material-related factors, lack of materials in markets, and delays in materials delivery to the site [26].

The findings of the study revealed the different factors affecting in cost management in construction projects which found in literature review of different researchers in different countries as in the following chart, indicate the most important factors affected in cost management in different countries.

\section{CONCLUSION}

Cost is one of the important key factors affected of construction performance, its need to manage and control along a life cycle of construction project. So cost management is important in construction project to ensure the success of project, the most factors affected in cost management that indicated through literature review in this study are: Poor scope definition, Inaccurate activity cost estimate, Poor work breakdown structure definition, Change in schedule, Unrealistic time schedule imposed in contract, Ineffective frequency of project budget updates, Lack of proper training and experience of project manager, Not implementing project management tools like primavera and other management software's. The majority of construction project in different countries suffered from cost overrun, cost management reduce it and help the project managers to achieve the success in their projects, so this study encourage the engineers and other parts interested in construction projects to implement the cost management actively. Various studies can be done in the future with different to indicate other factors or to do deep studies for the same factors, to help the stock holders in construction project to understand the cost management and how to apply it along the life cycle of project.

\section{ACKNOWLEDGMENTS}

This research is supported by Universiti Malaysia Pahang (Grant No PGRS190316) 


\section{REFERENCES}

[1] Govindarajan V \& Govindarajan S 1993 Strategic cost management: The new tool for competitive advantage, Simon and Schuster.

[2] Divakar K 2018 Factors affecting effective implementation of cost management process in construction industry.

[3] Burke D S, Beiter K \& Ishii K 1992 Life-cycle design for recyclability. Ohio State University.

[4] Halepota H A 2005 Motivational theories and their application in construction. Cost engineering, 4714.

[5] Ashworth A \& Perera S 2018 Contractual procedures in the construction industry, Routledge.

[6] Heralova R S 2017 Life cycle costing as an important contribution to feasibility study in construction projects. Procedia Engineering 196 565-570.

[7] Jakob M 2006 Marginal costs and co-benefits of energy efficiency investments: The case of the Swiss residential sector (Energy policy) 34 172-187.

[8] Ali A \& Kamaruzzaman S 2010 Cost performance for building construction projects in Klang valley. Journal of Building Performance.

[9] Dehghan R \& Ruwanpura J 2011 The mechanism of design activity overlapping in construction projects and the time-cost tradeoff function, Procedia Engineering 14 19591965.

[10] Ahmed S M, Azhar S, Kappagntula P \& Gollapudil D 2003 Delays in construction: a brief study of the Florida construction industry. Proceedings of the 39th Annual ASC Conference, $\quad$ Clemson University, Clemson, SC, 66.

[11] Assaf S A, Al-khalil M \& Al-hazmi M 1995 Causes of delay in large building construction projects. Journal of management in engineering 11 45-50.

[12] Mezher T M \& Tawil W 1998 Causes of delays in the construction industry in Lebanon. Engineering. Construction and Architectural Management 5 252-260.

[13] Yang J B \& Wei P R 2010 Causes of delay in the planning and design phases for construction projects. Journal of Architectural Engineering 16 80-83.

[14] Sriprasert E 2000 Assessment of cost control system: A case study of Thai Construction Organizations. Asian Institute of Technology, Bangkok.

[15] Koushki P, Al-rashid K \& Kartam N 2005 Delays and cost increases in the construction of private residential projects in Kuwait. Construction Management and Economics 23 285294.

[16] Sanvido V E \& Norton K J 1994 Integrated design-process model. Journal of Management in Engineering 10 55-62.

[17] Azis A A A, Memon A H, Rahman I A, Latif Q B A I \& Nagapan S Cost management of large construction projects in south Malaysia. Business, Engineering and Industrial Applications (ISBEIA), 2012 IEEE Symposium on, 2012. IEEE) 625-629.

[18] Fagbenle O I, Joshua O, Afolabi A, Ojelabi R A, Fagbenle O, Fagbenle A O \& Akomolafe M 2018 Cost management practice of construction firms and its influencing factors: Lessons from South Western Nigeria.

[19] Iyer K \& Jha K 2005 Factors affecting cost performance: evidence from Indian construction projects. International Journal of Project Management 23 283-295.

[20] Hatamleh M T, Hiyassat M, Sweis G J \& Sweis R J 2018 Factors affecting the accuracy of cost estimate: case of Jordan. Engineering, Construction and Architectural Management $25113-131$.

[21] Sinesilassie E, Tabish S \& Jha K 2018 Critical factors affecting cost performance: a case of Ethiopian public construction projects. International Journal of Construction Management 18,108-119.

[22] Soewin E \& Chinda T Factors affecting construction performance: exploratory factor analysis IOP Conference Series: Earth and Environmental Science, 2018. 
[23] Shehu Z, Endut I R, Akintoye A \& Holt G D 2014 Cost overrun in the Malaysian construction industry projects: A deeper insight. International Journal of Project Management 32 1471-1480.

[24] Niazi G A \& Painting N 2017 Significant factors causing cost overruns in the construction industry in Afghanistan. Procedia Engineering 182 510-517.

[25] Wanjari S P \& Dobariya G 2016 Identifying factors causing cost overrun of the construction projects in India (Sādhanā) 41 679-693.

[26] Enshassi A, Al-najjar J \& Kumaraswamy M 2009 Delays and cost overruns in the construction projects in the Gaza Strip. Journal of Financial Management of Property and Construction 14 126-151.

[27] Elinwa A U \& Buba S A 1993 Construction cost factors in Nigeria. Journal of Construction Engineering and Management 119 698-713.

[28] Omoregie A \& Radford D Polycentric cultural framework for infrastructure procurement in Nigeria. Proceedings $22^{\text {nd }}$ Annual ARCOM Conference, 2006. Association of Researchers in Construction Management).

[29] Maqsoom A, Khan M U, Khan M T, Khan S \& Ullah F 2018 Factors Influencing the Construction Time and Cost Overrun in Projects: Empirical Evidence from Pakistani Construction Industry. Proceedings of the 21st International Symposium on Advancement of Construction Management and Real Estate, 2018. Springer 769-778.

[30] Nawaz T, Shareef N A \& Ikram A A 2013 Cost performance in construction industry of Pakistan. Industrial Engineering Letters 3 19-33.

[31] Azhar N, Farooqui R U \& Ahmed S M Cost overrun factors in construction industry of Pakistan. First International Conference on Construction In Developing Countries (ICCIDC-I)“Advancing and Integrating Construction Education, Research \& Practice, 2008 4-5.

[32] Enshassi A, Mohamed S \& Abushaban S 2009b Factors affecting the performance of construction projects in the Gaza strip. Journal of Civil engineering and Management 15 269-280.

[33] Kashiwagi D Analysis of Cost Overruns in Saudi Arabia Construction Projects: A University Case Study.

[34] Alhomidan A 2013 Factors affecting cost overrun in road construction projects in Saudi Arabia International Journal of Civil \& Environmental Engineering 13 1-4.

[35] Bubshait A A \& Al-juwairah Y A 2002 Factors contributing to construction costs in Saudi Arabia. Cost Engineering 4430.

[36] Sweis G J, Sweis R, Rumman M A, Hussein R A \& Dahiyat S E 2013 Cost overruns in public construction projects: the case of Jordan. Journal of American Science 9 134-141.

[37] Bekr G A 2015 Identifying Factors Leading to Cost Overrun in Construction Projects in Jordan.

[38] Toh T C, Ting C, Ali K N, Aliagha G U \& Munir O 2012 Critical cost factors of building construction projects in Malaysia. Procedia-Social and Behavioral Sciences 57 360-367.

[39] Mydin M O, Sani N M, Salim N A \& Alias N M 2014 Assessment of Influential Causes of Construction Project Delay in Malaysian Private Housing from Developer's Viewpoint, E3S Web of Conferences, EDP Sciences, 01027.

[40] Memon A H 2014 Contractor perspective on time overrun factors in Malaysian construction projects. International Journal of Science, Environment and Technology 3 1184-11. 